\title{
Estimation of the Relative Severity of Floods in Small Ungauged Catchments for Preliminary Observations on Flash Flood Preparedness: A Case Study in Korea
}

\section{Eung Seok Kim ${ }^{1}$ and Hyun Il Choi ${ }^{2, *}$}

1 Department of Civil Engineering, Sunmoon University, 100, Kalsan-ri, Tangjeong-myeon, Asan-si, Chungnam-do 336-708, Korea; E-Mail: hydrokes@sunmoon.ac.kr

2 Department of Civil Engineering, Yeungnam University, 214-1, Dae-dong, Gyeongsan-si, Gyeongbuk-do 712-749, Korea

* Author to whom correspondence should be addressed; E-Mail: hichoi@ynu.ac.kr; Tel.: +82-53-810-2413; Fax: +82-53-810-4622.

Received: 8 March 2012; in revised form: 31 March 2012 / Accepted: 6 April 2012 /

Published: 18 April 2012

\begin{abstract}
An increase in the occurrence of sudden local flooding of great volume and short duration has caused significant danger and loss of life and property in Korea as well as many other parts of the World. Since such floods usually accompanied by rapid runoff and debris flow rise quite quickly with little or no advance warning to prevent flood damage, this study presents a new flash flood indexing methodology to promptly provide preliminary observations regarding emergency preparedness and response to flash flood disasters in small ungauged catchments. Flood runoff hydrographs are generated from a rainfall-runoff model for the annual maximum rainfall series of long-term observed data in the two selected small ungauged catchments. The relative flood severity factors quantifying characteristics of flood runoff hydrographs are standardized by the highest recorded maximum value, and then averaged to obtain the flash flood index only for flash flood events in each study catchment. It is expected that the regression equations between the proposed flash flood index and rainfall characteristics can provide the basis database of the preliminary information for forecasting the local flood severity in order to facilitate flash flood preparedness in small ungauged catchments.
\end{abstract}

Keywords: flash flood index; flash flood preparedness; flood severity; runoff hydrograph 


\section{Introduction}

Climate change poses one of the greatest threats to the World's environment, already contributing to visible impacts on human health, economic activity, food security, agriculture, natural environment and ecosystems, water and other natural resources, physical infrastructure, and so on. The Fourth Report of the Intergovernmental Panel on Climate Change (IPCC) has brought to the fore the severity and global dimension of the impacts of climate change. It was reported that while the number of rainy days has decreased, the occurrence of more intense rainfall events has increased in most parts of Asia, which has led to severe floods, landslides, and debris and mud flows [1]. The climate change could be even more noticeable in Korea. According to the Korea Meteorological Administration (KMA), the Korean Peninsula is warming at more than twice the speed of the global average, and the yearly precipitation has increased approximately 19 percent in the period of 1912-2008 with an increase in summer precipitation and localized torrential downpours. As the temporal and spatial fluctuations of the precipitation are expected to increase, most watersheds in the Korean Peninsula have climatic and geomorphic vulnerability to flash floods caused by localized convective storms of short duration over small catchments. Flash flooding is a sudden local flood of great volume and short duration, which is now a common natural disaster in Korea. The annual natural disaster bulletin of Korea National Emergency Management Agency (KNEMA) reported that some watershed areas were inundated with the rapid debris flow runoff raising some flood damage such as bank erosion and bridge collapse [2]. It is, however, quite tough to cope with such types of flood damage, because local flooding in small watersheds rises quite quickly with little or no advance flood warning. There is a limit on predicting a sudden local flood in small watersheds through most present flood forecasting systems based on a rainfall-runoff model with high computational time [3-6]. It is therefore required to characterize the hydrologic behavior of local flooding that occurs in small catchments with the short flood response time in order to establish an appropriate and effective emergency preparedness and response system to flash flood disasters.

Many studies have examined flash floods mainly from a climatological perspective, especially focused on the temporal and spatial characteristics of rainfall, such as for the determination of climatological characteristics of flash floods and extreme rain events [7-11], and recently for the use of radar information in flash flood prediction [12-16]. From the hydrological perspective on flash floods, post-flood estimations of peak discharges have been extensively conducted in various countries to provide the effective documentation of flash flood events and enhance understanding on regional behavior of extreme events [17-26]. In order to better understand the hydro-meteorological processes leading to flash floods, the EU Hydrometeorological Data Resources and Technology for Effective Flash Flood Forecasting Project (HYDRATE) was established, and has studied on enhancing the capability of flash flood forecasting [27-31]. In the US, for the flash flood guidance (FFG)-based flash flood warnings and watches issued by National Weather Service (NWS), many studies have focused on derivation of the geomorphological and climatological instantaneous unit hydrograph, estimation of the threshold runoff, development of geographic information system (GIS)-based procedures in support of the FFG, and so on [3,32-35]. On the other hand, Kyiamah [36] and Bhaskar et al. [37] initially characterized flash floods from a runoff perspective using flood runoff hydrographs. They presented a flash flood index evaluated by relative severity factors quantifying characteristics of the 
observed hydrographs such as rising curve gradient, flood magnitude ratio, and flood response time in order to distinguish flash floods from other floods. Following the methodology suggested by Bhaskar et al. [37], Jung [38] estimated the flash flood index for several flood events of the Bo-chung River basin in Korea. However, these studies have the problematic issue of quantifying the three relative severity factors by each using a different ordinal scale of assignment where the choice of class intervals is to some extent arbitrary. Kim and Kim [5] estimated the flash flood index for investigating the relative severity of flash floods in the Han River basin with 101 flood events, and quantified the flash flood severity for some flood events caused by heavy rainfall in July of 2006. Whereas most previous studies computed the flash flood index directly from the observed flood hydrographs, Kim and Choi [39] made an attempt to evaluate vulnerability to extreme flash floods in design storms through the flash flood index for small ungauged catchments where rainfall observations are usually available.

This study has modified the flash flood index from Bhaskar et al. [37], and presented a new methodology to measure the relative severity of local flash flooding in small ungauged catchments by a dimensionless flash flood index from the normalized relative severity factors on the same scale ratio to the highest recorded maximum value. This flash flood index is obtained by quantifying the characteristics of hydrographs generated from a rainfall-runoff model, Hydrologic Engineering CenterHydrologic Modeling System (HEC-HMS), for the annual maximum rainfall series of long-term observed data. The developed flash flood index is implemented in the two selected small ungauged basins of Korea, the Oui-mi River basin located in the hilly region and the Mae-gok River basin in the relatively flat region. The regression analysis of relationships between the flash flood index and rainfall characteristics presented in this study can provide better understanding of the hydrologic behavior of local flash flooding for the preliminary information on an emergency preparedness and response system to flash flood disasters in small ungauged catchments.

\section{Study Catchments}

This study selected the two small ungauged natural catchments, the Oui-mi River basin in a hilly slope terrain and the Mae-gok River basin with a flat topography, for study basins around which rainfall gauge stations have recorded the long-term hourly rainfall data. The location and shape of study basins are shown in Figure 1, and the summary of the characteristics of the two basins under study are presented in Table 1.

Table 1. The summary of characteristics for the two study basins.

\begin{tabular}{|c|c|c|c|c|c|c|}
\hline $\begin{array}{l}\text { Basin } \\
\text { Name }\end{array}$ & $\begin{array}{c}\text { Bain } \\
\text { Area } \\
\text { A }\left(\mathbf{k m}^{2}\right) \\
\end{array}$ & $\begin{array}{c}\text { Basin } \\
\text { Length } \\
\text { L (km) } \\
\end{array}$ & $\begin{array}{c}\text { Basin } \\
\text { Width } \\
\text { A/L }(\mathbf{k m}) \\
\end{array}$ & $\begin{array}{c}\text { Shape } \\
\text { Factor } \\
\text { A/L }{ }^{2} \\
\end{array}$ & $\begin{array}{c}\text { Average } \\
\text { Elevation } \\
\text { (EL.m) }\end{array}$ & $\begin{array}{c}\text { Average } \\
\text { Slope } \\
(\%) \\
\end{array}$ \\
\hline The Oui-mi River & 16.74 & 7.52 & 2.23 & 0.30 & 544.9 & 53.4 \\
\hline The Mae-gok River & 35.48 & 11.25 & 3.15 & 0.28 & 65.0 & 9.6 \\
\hline
\end{tabular}


Figure 1. Basin maps for (a) the Oui-mi River and (b) the Mae-gok River.

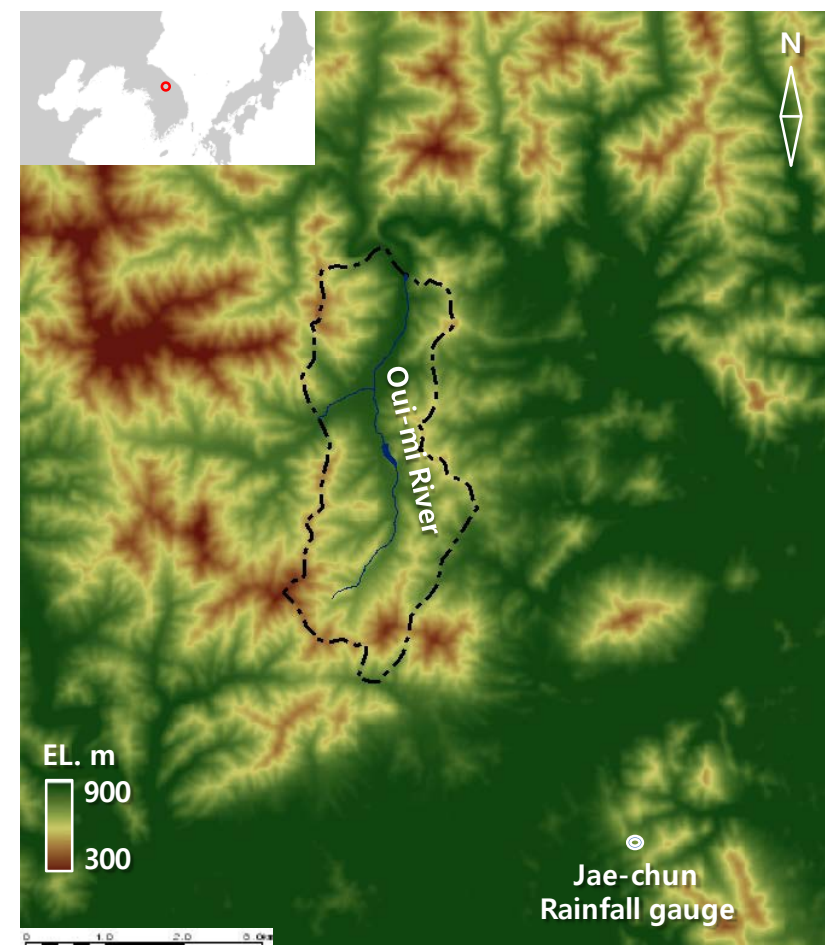

(a)

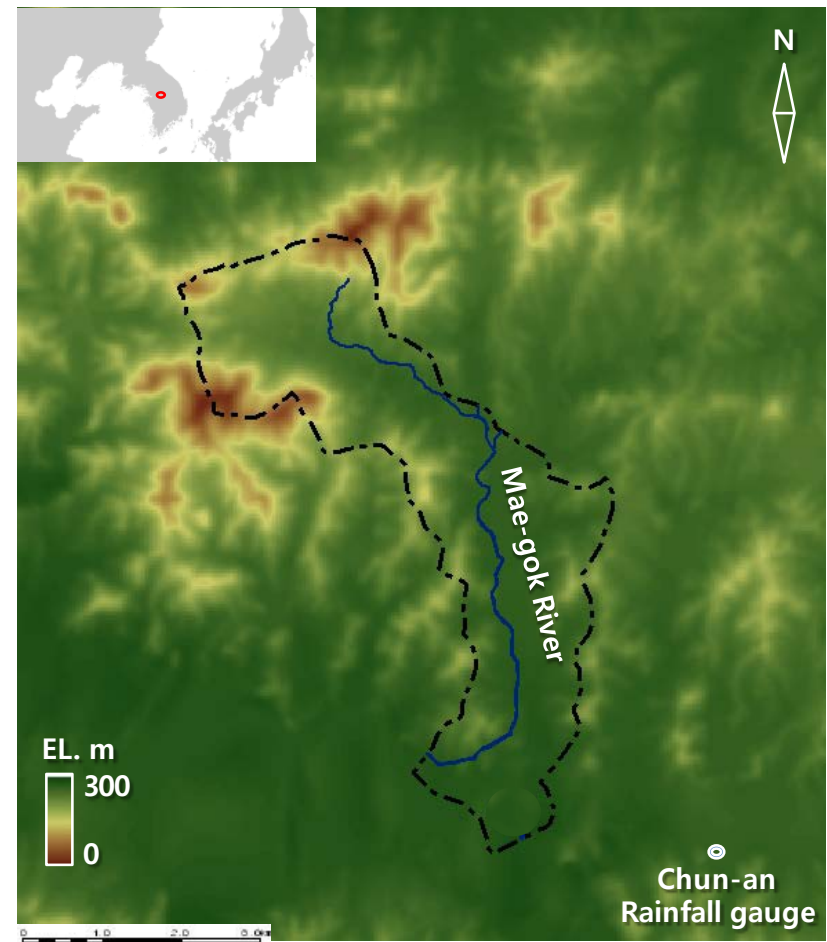

(b)

The Oui-mi River basin is a small hilly drainage basin of $16.74 \mathrm{~km}^{2}$ size and $7.52 \mathrm{~km}$ length, located between $128^{\circ} 11^{\prime} \sim 128^{\circ} 12^{\prime} \mathrm{E}$ and $37^{\circ} 15^{\prime} \sim 37^{\circ} 16^{\prime} \mathrm{N}$ [40]. The basin is a natural drainage area where land cover types consist mainly of forests (86.3\%) and croplands (11.2\%). This basin located in a mountainous inland area is characterized by a continental climate with cold winters and hot summers. The average annual temperature is $10.3^{\circ} \mathrm{C}$, and the average monthly temperature ranges from $-2.7^{\circ} \mathrm{C}$ in January to $23.4^{\circ} \mathrm{C}$ in August. Annual maximum rainfall data was collected for the period of 1973-2008 from the Jae-chun gauge station which has a self-recording rain gauge managed by the Korea Meteorological Administration. The data showed that the annual mean rainfall volume is $1,322.5 \mathrm{~mm}$, greater than the national average of $1,283.0 \mathrm{~mm}$ over the same period, as a result of proximity to the mountainous region. The highest recorded maximum depth of a rainfall event was $228.5 \mathrm{~mm}$ in 11 September 1990.

The Mae-gok River basin was also selected to investigate flood characteristics for the small flat drainage area and compare results with those in the Oui-mi River basin. This river basin is located between $127^{\circ} 02^{\prime} \sim 127^{\circ} 08^{\prime} \mathrm{E}$ and $36^{\circ} 47^{\prime} \sim 36^{\circ} 52^{\prime} \mathrm{N}$ with $35.48 \mathrm{~km}^{2}$ size and $11.25 \mathrm{~km}$ length [41]. Land cover types within the basin are mainly $44 \%$ croplands and $36 \%$ forests. Annual maximum rainfall event series during 1973-2008 was collected from a self-recording rain gauge in the Chun-an gauge station managed by the Korea Meteorological Administration. The annual mean rainfall volume is 1,235.9 $\mathrm{mm}$, little less than the national average rainfall over the same period, and the highest recorded maximum depth of a rainfall event was $262.5 \mathrm{~mm}$ in 9 August 1995. The average annual temperature is $11.6^{\circ} \mathrm{C}$, and the average monthly temperature ranges from $-3.0^{\circ} \mathrm{C}$ in January to $24.9^{\circ} \mathrm{C}$ in August. 


\section{Estimation of Flash Flood Severity}

This study presents a new flash flood index estimated from the simulated runoff hydrographs for the annual maximum precipitation series to quantify the severity of flash floods in small ungauged catchments. Bhaskar et al. [37] characterized the flash flood severity using a flash flood index evaluated directly from the observed hydrograph characteristics such as the rising curve gradient $K$, the flood magnitude ratio $M$, and the flood response time $T$. These characteristics were quantified as the relative severity factors $R K, R M$, and $R T$, respectively, by using each different ordinal scale of assignment where the choice of class intervals is to somewhat arbitrary. Since Bhaskar et al. [37] presented the flash flood index $R F$ by the sum of such problematic severity factors on different ordinal scale values, Kim and Choi [39] computed all relative severity factors at the same scale ratio to each highest recorded maximum value. They also demonstrated that the flash flood index from the two relative severity factors $R K$ and $R M$, which avoids double-counted relative severity factors with similar characteristics such as $R K$ and $R T$, is more adequate to estimate the relative flood severity in small ungauged catchment. This study determines the flash flood index FI by the average of the two relative severity factors $R K$ and $R M$ standardized by the highest maximum value for flash flood events only. Details of the flash flood indexing procedure are discussed below.

\subsection{Flood Runoff Hydrographs}

Flood runoff hydrographs are generated from a rainfall-runoff model, HEC-HMS [42], using annual maximum precipitation series for past 36 years during 1973-2008 from the Jae-chun gauge station for the Oui-mi River basin and the Chun-an gauge station for the Mae-gok River basin, respectively. The annual maximum precipitation series for the two rain gauge stations were constituted by selecting the maximum depth for a rainfall period among all rainfall events recorded in each year. The NRCS (Natural Resources Conservation Service) curve number method [43] is used for the loss rate method, and the Clark unit hydrograph [44] is employed for the transform method for rainfall-runoff simulations in both basins. The NRCS curve number is averaged for the Oui-mi River basin as 70.10 and for the Mae-gok River basin as 87.92, respectively. The storage coefficient of the Clark unit hydrograph is estimated for the Oui-mi River basin as $1.18 \mathrm{~h}$ and for the Mae-gok River basin as $2.02 \mathrm{~h}$, respectively. Note that both parameter values are directly referred in the basic plan reports for the river maintenance works by Wonju city [40] for the Oui-mi River basin, and Chungcheongnam province [41] for the Mae-gok River basin, respectively, which were used for estimating the design flood discharges that have been officially announced for both study basins. The maximum peak flood discharge of $183.3 \mathrm{~m}^{3} / \mathrm{s}$ is estimated for the Oui-mi River basin in 5 August 2007 (see the second column of Table 2), and the maximum peak flood discharge of $352.8 \mathrm{~m}^{3} / \mathrm{s}$ is computed for the Mae-gok River basin in 9 August 1995 (see the second column of Table 3), respectively, among the annual maximum simulated hydrographs during the analysis period of 1973-2008. 
Table 2. Summary of runoff and indexing characteristics along with rainfall data for the selected flood events among 36-year annual maximum series in the Oui-mi River basin.

\begin{tabular}{|c|c|c|c|c|c|c|c|c|c|c|c|c|c|c|c|c|c|c|}
\hline \multicolumn{5}{|c|}{ Flood Runoff Characteristics } & \multicolumn{5}{|c|}{ Flash Flood Indexing Parameters } & \multicolumn{9}{|c|}{ Rainfall Characteristics } \\
\hline \multirow{5}{*}{ No } & Flood & Flood & Time to & Time to & Flood & Rising & Relative & Relative & Flash & Average & Max & Max & $\operatorname{Max}$ & Max & Max & $\operatorname{Max}$ & Total & Rainfall \\
\hline & Event & Peak & Flooding & Flooding & Magnitude & Curve & Flood & Flood & Flood & Rainfall & 1-h & 2-h & 3-h & 4-h & 5-h & 6-h & Rainfall & Duration \\
\hline & Date & Discharge & Start & Peak & Ratio & Gradient & Severity & Severity & Index & Intensity & Rainfall & Rainfall & Rainfall & Rainfall & Rainfall & Rainfall & Depth & Time \\
\hline & (mm/dd/yy) & $\mathrm{Q}_{\mathrm{p}}\left(\mathrm{m}^{3} / \mathrm{s}\right)$ & $\mathrm{T}_{\mathrm{b}}(\mathrm{h})$ & $\mathrm{T}_{\mathrm{p}}(\mathrm{h})$ & M & $\mathrm{K}\left(\mathrm{mm} / \mathrm{h}^{2}\right)$ & $\mathrm{RM}$ & $\mathrm{RK}$ & FI (\%) & $\mathrm{I}_{\mathrm{a}}(\mathrm{mm})$ & $\mathrm{R}_{1 \mathrm{~h}}(\mathrm{~mm})$ & $\mathrm{R}_{2 \mathrm{~h}}(\mathrm{~mm})$ & $\mathrm{R}_{3 \mathrm{~h}}(\mathrm{~mm})$ & $\mathrm{R}_{4 \mathrm{~h}}(\mathrm{~mm})$ & $\mathrm{R}_{5 \mathrm{~h}}(\mathrm{~mm})$ & $\mathrm{R}_{6 \mathrm{~h}}(\mathrm{~mm})$ & $\mathrm{R}_{\mathrm{t}}(\mathrm{mm})$ & $\mathrm{D}(\mathrm{h})$ \\
\hline & [1] & {$[2]$} & {$[3]$} & {$[4]$} & [5] & {$[6]$} & [7] & [8] & [9] & {$[10]$} & {$[11]$} & {$[12]$} & {$[13]$} & {$[14]$} & {$[15]$} & {$[16]$} & [17] & [18] \\
\hline 1 & 07/22/80 & 71.7 & 16.9 & 17.0 & 1.1 & 11.7 & 0.4 & 0.6 & 50.8 & 6.6 & 43.0 & 53.2 & 75.4 & 85.6 & 91.1 & 95.9 & 132.6 & 20.0 \\
\hline 2 & 07/19/86 & 80.5 & 6.5 & 7.0 & 1.2 & 6.9 & 0.4 & 0.4 & 40.4 & 6.4 & 32.0 & 58.0 & 69.0 & 78.5 & 86.0 & 97.0 & 134.2 & 21.0 \\
\hline 3 & $07 / 22 / 87$ & 70.0 & 3.8 & 4.0 & 1.1 & 4.4 & 0.4 & 0.2 & 30.9 & 8.2 & 41.5 & 57.5 & 67.5 & 82.0 & 92.0 & 101.5 & 187.5 & 23.0 \\
\hline 4 & 07/14/88 & 111.5 & 8.6 & 12.0 & 1.7 & 3.0 & 0.6 & 0.2 & 38.3 & 14.0 & 33.0 & 57.0 & 75.5 & 99.5 & 118.0 & 134.0 & 223.5 & 16.0 \\
\hline 5 & 07/26/89 & 77.4 & 5.8 & 7.0 & 1.2 & 2.2 & 0.4 & 0.1 & 27.0 & 6.2 & 34.0 & 67.5 & 85.5 & 89.5 & 95.0 & 99.0 & 143.0 & 23.0 \\
\hline 6 & 09/11/90 & 92.8 & 23.3 & 24.0 & 1.4 & 8.3 & 0.5 & 0.4 & 47.5 & 9.5 & 38.5 & 72.0 & 88.0 & 93.5 & 94.5 & 102.0 & 228.5 & 24.0 \\
\hline 7 & 07/13/93 & 70.4 & 12.8 & 13.0 & 1.1 & 7.5 & 0.4 & 0.4 & 39.1 & 7.5 & 30.5 & 42.0 & 52.5 & 63.5 & 69.0 & 75.0 & 158.5 & 21.0 \\
\hline 8 & 06/30/94 & 123.6 & 18.9 & 20.0 & 1.9 & 11.8 & 0.7 & 0.6 & 65.1 & 8.5 & 37.0 & 68.5 & 90.5 & 94.0 & 100.0 & 102.5 & 196.5 & 23.0 \\
\hline 9 & 07/01/97 & 98.7 & 16.6 & 18.0 & 1.5 & 5.1 & 0.5 & 0.3 & 40.4 & 7.2 & 49.5 & 56.5 & 63.5 & 69.5 & 73.5 & 79.0 & 166.5 & 23.0 \\
\hline 10 & 06/30/01 & 98.3 & 4.1 & 5.0 & 1.5 & 8.4 & 0.5 & 0.4 & 49.2 & 17.8 & 41.0 & 72.0 & 87.0 & 93.5 & 104.0 & 106.5 & 106.5 & 6.0 \\
\hline 11 & 07/16/06 & 67.5 & 14.5 & 15.0 & 1.0 & 1.2 & 0.4 & 0.1 & 21.5 & 8.5 & 22.5 & 42.0 & 54.5 & 71.0 & 86.0 & 91.0 & 203.0 & 24.0 \\
\hline 12 & 08/05/07 & 183.3 & 5.6 & 7.0 & 2.8 & 18.8 & 1.0 & 1.0 & 100.0 & 18.7 & 68.0 & 122.5 & 149.0 & 161.0 & 171.5 & 180.5 & 186.5 & 10.0 \\
\hline 13 & 07/24/08 & 70.6 & 17.9 & 19.0 & 1.1 & 1.1 & 0.4 & 0.1 & 22.3 & 4.0 & 49.0 & 63.0 & 68.0 & 69.5 & 74.0 & 77.5 & 96.5 & 24.0 \\
\hline & Maximum & 183.3 & 23.3 & 24.0 & 2.8 & 18.8 & 1.0 & 1.0 & 100.0 & 18.7 & 68.0 & 122.5 & 149.0 & 161.0 & 171.5 & 180.5 & 228.5 & 24.0 \\
\hline & Minimum & 67.5 & 3.8 & 4.0 & 1.0 & 1.1 & 0.4 & 0.1 & 21.5 & 4.0 & 22.5 & 42.0 & 52.5 & 63.5 & 69.0 & 75.0 & 96.5 & 6.0 \\
\hline
\end{tabular}


Table 3. Summary of runoff and indexing characteristics along with rainfall data for the selected flood events among 36-year annual maximum series in the Mae-gok River basin.

\begin{tabular}{|c|c|c|c|c|c|c|c|c|c|c|c|c|c|c|c|c|c|c|}
\hline & \multicolumn{4}{|c|}{ Flood Runoff Characteristics } & \multicolumn{5}{|c|}{ Flash Flood Indexing Parameters } & \multicolumn{9}{|c|}{ Rainfall Characteristics } \\
\hline \multirow{5}{*}{ No } & Flood & Flood & Time to & Time to & Flood & Rising & Relative & Relative & Flash & Average & Max & Max & $\operatorname{Max}$ & $\operatorname{Max}$ & Max & $\operatorname{Max}$ & Total & Rainfall \\
\hline & Event & Peak & Flooding & Flooding & Magnitude & Curve & Flood & Flood & Flood & Rainfall & 1-h & 2-h & 3-h & 4-h & 5-h & 6-h & Rainfall & Duration \\
\hline & Date & Discharge & Start & Peak & Ratio & Gradient & Severity & Severity & Index & Intensity & Rainfall & Rainfall & Rainfall & Rainfall & Rainfall & Rainfall & Depth & Time \\
\hline & (mm/dd/yy) & $\mathrm{Q}_{\mathrm{p}}\left(\mathrm{m}^{3} / \mathrm{s}\right)$ & $\mathrm{T}_{\mathrm{b}}(\mathrm{h})$ & $\mathrm{T}_{\mathrm{p}}(\mathrm{h})$ & $\mathrm{M}$ & $\mathrm{K}\left(\mathrm{mm} / \mathrm{h}^{2}\right)$ & $\mathrm{RM}$ & RK & FI (\%) & $\mathrm{I}_{\mathrm{a}}(\mathrm{mm})$ & $\mathrm{R}_{1 \mathrm{~h}}(\mathrm{~mm})$ & $\mathrm{R}_{2 \mathrm{~h}}(\mathrm{~mm})$ & $\mathrm{R}_{3 \mathrm{~h}}(\mathrm{~mm})$ & $\mathrm{R}_{4 \mathrm{~h}}(\mathrm{~mm})$ & $\mathrm{R}_{5 \mathrm{~h}}(\mathrm{~mm})$ & $\mathrm{R}_{6 \mathrm{~h}}(\mathrm{~mm})$ & $\mathrm{R}_{\mathrm{t}}(\mathrm{mm})$ & $\mathrm{D}(\mathrm{h})$ \\
\hline & [1] & [2] & {$[3]$} & [4] & [5] & [6] & [7] & [8] & [9] & {$[10]$} & {$[11]$} & [12] & [13] & {$[14]$} & {$[15]$} & {$[16]$} & [17] & [18] \\
\hline 1 & $08 / 14 / 76$ & 209.2 & 1.8 & 3.0 & 1.4 & 5.4 & 0.6 & 0.6 & 57.2 & 10.5 & 49.5 & 94.5 & 107.5 & 115.4 & 115.4 & 115.4 & 125.6 & 12.0 \\
\hline 2 & 09/06/77 & 180.7 & 6.9 & 8.0 & 1.2 & 3.0 & 0.5 & 0.3 & 40.7 & 7.4 & 37.0 & 73.5 & 84.5 & 91.0 & 100.6 & 104.6 & 147.7 & 20.0 \\
\hline 3 & 08/16/78 & 189.2 & 7.9 & 9.0 & 1.3 & 3.9 & 0.5 & 0.4 & 46.5 & 13.7 & 27.5 & 54.0 & 76.0 & 101.5 & 117.0 & 119.0 & 123.0 & 9.0 \\
\hline 4 & 07/14/80 & 198.5 & 4.2 & 5.0 & 1.3 & 6.8 & 0.6 & 0.7 & 62.7 & 15.5 & 46.0 & 73.0 & 96.5 & 104.5 & 107.5 & 108.0 & 108.5 & 7.0 \\
\hline 5 & 07/28/82 & 180.7 & 7.0 & 8.0 & 1.2 & 3.6 & 0.5 & 0.4 & 43.6 & 8.3 & 44.5 & 61.0 & 86.5 & 95.0 & 104.0 & 116.0 & 166.0 & 20.0 \\
\hline 6 & 07/04/84 & 210.6 & 6.6 & 8.0 & 1.4 & 4.5 & 0.6 & 0.5 & 52.5 & 7.5 & 39.5 & 58.0 & 75.0 & 91.0 & 114.5 & 133.0 & 158.0 & 21.0 \\
\hline 7 & 07/19/86 & 171.3 & 4.3 & 5.0 & 1.2 & 3.3 & 0.5 & 0.3 & 41.2 & 13.4 & 34.0 & 57.0 & 83.0 & 106.0 & 111.0 & 114.0 & 120.2 & 9.0 \\
\hline 8 & 07/21/87 & 175.0 & 17.1 & 18.0 & 1.2 & 3.3 & 0.5 & 0.3 & 41.6 & 7.8 & 31.5 & 53.5 & 79.5 & 85.5 & 88.5 & 89.0 & 149.0 & 19.0 \\
\hline 9 & 08/27/92 & 179.1 & 9.7 & 11.0 & 1.2 & 2.5 & 0.5 & 0.3 & 38.0 & 7.6 & 29.5 & 49.5 & 61.0 & 90.5 & 107.5 & 119.5 & 159.5 & 21.0 \\
\hline 10 & 08/09/95 & 352.8 & 3.9 & 6.0 & 2.4 & 9.9 & 1.0 & 1.0 & 100.0 & 23.9 & 67.5 & 103.5 & 132.5 & 156.5 & 175.5 & 200.5 & 262.5 & 11.0 \\
\hline 11 & 07/01/97 & 209.7 & 11.8 & 13.0 & 1.4 & 5.5 & 0.6 & 0.6 & 57.4 & 8.0 & 33.0 & 62.5 & 86.0 & 99.5 & 108.5 & 113.5 & 151.5 & 19.0 \\
\hline 12 & 08/07/01 & 200.5 & 5.6 & 7.0 & 1.4 & 3.8 & 0.6 & 0.4 & 47.6 & 18.4 & 35.5 & 65.5 & 80.5 & 91.0 & 113.0 & 128.0 & 128.5 & 7.0 \\
\hline 13 & 08/07/02 & 240.1 & 8.6 & 13.0 & 1.6 & 2.2 & 0.7 & 0.2 & 44.9 & 14.9 & 37.5 & 64.0 & 86.0 & 105.0 & 133.0 & 161.0 & 239.0 & 16.0 \\
\hline \multirow[t]{3}{*}{14} & 09/18/05 & 164.7 & 9.0 & 10.0 & 1.1 & 1.8 & 0.5 & 0.2 & 32.3 & 10.2 & 33.5 & 56.5 & 81.0 & 89.0 & 99.5 & 103.0 & 112.0 & 11.0 \\
\hline & Maximum & 352.8 & 17.1 & 18.0 & 2.4 & 9.9 & 1.0 & 1.0 & 100.0 & 23.9 & 67.5 & 103.5 & 132.5 & 156.5 & 175.5 & 200.5 & 262.5 & 21.0 \\
\hline & Minimum & 164.7 & 1.8 & 3.0 & 1.1 & 1.8 & 0.5 & 0.2 & 32.3 & 7.4 & 27.5 & 49.5 & 61.0 & 85.5 & 88.5 & 89.0 & 112.0 & 7.0 \\
\hline
\end{tabular}




\subsection{Flood Magnitude Ratio}

Bhaskar et al. [37] presented the flood magnitude ratio $M$, which means a ratio of the peak flood discharge $Q_{p}$ to the long-term average discharge $Q_{a}$ :

$$
M=Q_{p} / Q_{a}
$$

The long-term average discharge $Q_{a}$ is also not available in ungauged catchments. Furthermore, we need to define a threshold discharge distinguishing a flash flood event with the potential flooding risk from other normal stormwater runoff events for a watershed. For flash flood preparedness guidance purposes, a threshold runoff is defined as a ratio of stream flow at the bankfull stage to the unit hydrograph peak flow for a watershed [32]. The bankfull discharge can be determined by identifying the bankfull stage and then determining the discharge associated with the bankfull stage. Although many field indicators have been proposed, defining the bankfull stage is complicated [45]. Due to difficulties in the identification of bankfull discharge and the lack of measurements for the two ungauged study catchments, this study assumes the 2-year return period discharge as a threshold discharge following Wolman and Leopold [46]. Hence, the bankfull discharge $Q_{b}$ is replaced for $Q_{a}$ in Equation (1) to represent the relative amount of flood to the flooding threshold discharge:

$$
M=Q_{p} / Q_{b}
$$

The estimated threshold discharges for the 2-year return period are 64.9 and $147.1 \mathrm{~m}^{3} / \mathrm{s}$ in the Oui-mi River basin and the Mae-gok River basin, respectively. The value of the flood magnitude ratio $M$ varies from 1.0 to 2.8 for the Oui-mi River basin as shown in column 5 of Table 2, and varies from 1.1 to 2.4 for the Mae-gok River basin as shown in column 5 of Table 3, respectively. The flash flooding situation can be characterized only for flood events with the flood magnitude ratio $M$ greater than 1.

\subsection{Rising Curve Gradient}

Since floods that have short lag times between the storm and the peak discharge result in fast runoff concentration and in consequences high flooding hazard, a flash flood characterized by a rapid rate of rise with a high velocity means that the event is predicted to be hazardous. Hence, the rising curve gradient of hydrographs can represent the typical characteristics of flash floods that happen quickly at some location over a short time period. Bhaskar et al. [37] described the rising limb of hydrographs as an exponential equation, and thus the rising curve gradient $K$ (/day) can be computed as:

$$
K=\frac{\ln \left(Q_{t} / Q_{0}\right)}{t}
$$

where $Q_{0}$ is the specified initial discharge, and $Q_{t}$ is the discharge at a later time $t$ close to the time of peak. This exponential function popularly used for hydrograph recession curves has a difficulty in defining the specified initial discharge $Q_{0}$ for the simulated runoff hydrographs, which is usually zero. Also, sometimes finding the starting time of flood runoff hydrographs can be arbitrary and ambiguous in accordance with the shape of the rising limb. Moreover, both study basins have occasionally recorded a certain rainfall pattern that the incipient rain is moderate but torrential rain occurs abruptly in the middle of a rainfall duration time. Hence, this study expresses the rising limb gradient of 
simulated hydrographs using a mean slope gradient approximation between occurrence times $T_{p}$ and $T_{b}$ corresponding to the peak discharge $Q_{p}$ and the bankfull discharge $Q_{b}$ in the rising limb of a hydrograph, respectively:

$$
K=\frac{\left(Q_{p}-Q_{b}\right) / A}{T_{p}-T_{b}}
$$

where $A$ is the drainage area. The rising curve gradient $K$ is computed for the specific discharge (discharge per unit area) with a unit of $\mathrm{mm} / \mathrm{h}^{2}$. The range of values for the rising curve gradient $K$ is from 1.1 to $18.8 \mathrm{~mm} / \mathrm{h}^{2}$ for the Oui-mi River basin as shown in column 6 of Table 2, and is from 1.8 to $9.9 \mathrm{~mm} / \mathrm{h}^{2}$ for the Mae-gok River basin as shown in column 6 of Table 3, respectively. Since the rising curve gradient represents the steepness of the rising limb of flood hydrographs, the large values of parameter $K$ can be associated with a rapid local flood of great volume.

\subsection{Flash Flood Index}

The characteristics of flood hydrographs need to be integrated for an overall value to evaluate flash flood severity. Because the rising curve gradient $K$ and the flood magnitude ratio $M$ are measured at different scales and units, they need to be transformed into a common domain prior to combining them. In order to contribute equally to the analysis, the flood hydrograph characteristics are standardized by the maximum value:

$$
R S_{i}=\frac{S_{i}}{S_{\max }}
$$

where $S_{i}$ is the evaluation score for the flood hydrograph characteristics such as $K$ and $M$ for the $i$ th flood event, $S_{\max }$ is the highest value of $S_{i}$, and $R S_{i}$ is the relative severity factor of $S_{i}$. The flash flood index FI for each flood event is computed by taking the average of the two relative severity factors such as $R K$ and $R M$ :

$$
F I=\frac{R K+R M}{2} \times 100(\%)
$$

Note that only when the flood magnitude ratio $M$ is greater than 1, i.e., the peak discharge of a flood event is greater than the threshold bankfull discharge, the flash flood index is computed to distinguish a flash flood event from other normal stormwater runoff events. Consequently among the 36 annual maximum simulated hydrographs in the analysis period of 1973-2008 for the two study catchments, 13 and 14 floods are selected for flash flooding events in the Oui-mi River basin and the Mae-gok River basin as summarized in Tables 2 and 3, respectively.

\section{Flash Flood Preparedness Information}

Since local flooding in small watersheds rises quite quickly with little or no advance warning to prevent flash flood damage, flash flood forecasting does not require a complex numerical model consuming high computational time. Therefore, the analysis of the relationship between rainfall and runoff characteristics is important for understanding and forecasting flash flooding to promptly provide the preliminary observations on the effective emergency preparedness and initial response information 
to local flooding with a short period of time over a small area. This study has examined the relationship between the proposed flash flood index FI and rainfall characteristics for the selected flood events among 36-year annual maximum series in the two study basins. The analysis is performed by creating scatter plots and regression equations between the flash flood index FI and rainfall data such as the average rainfall intensity $I_{a}$, the maximum rainfall depths for the 1-h, 2-h, 3-h, 4-h, 5-h, and 6-h durations, $R_{1 h}, R_{2 h}, R_{3 h}, R_{4 h}, R_{5 h}$, and $R_{6 h}$, respectively, the total rainfall depth $R_{t}$, and the rainfall duration time $D$. The average rainfall intensity means the total amount of rainfall for a storm event divided by the duration of the storm. Tables 2 and 3 present flash flood index FI along with rainfall characteristics and runoff results for the two study basins, the Oui-mi River basin and the Mae-gok River basin, respectively. The scatter plots of the flash flood index FI versus each rainfall data are illustrated in Figure 2 for the Oui-mi River basin and Figure 3 for the Mae-gok River basin, respectively. Table 4 summarizes and compares the regression equations of the flash flood index FI corresponding to each rainfall data in the two study basins.

Figure 2. The comparison of trends between the flash flood index FI and rainfall characteristics such as; (a) the average rainfall intensity $I_{a}$; (b) the 1-h maximum rainfall depth $R_{1 h}$; (c) the 2-h maximum rainfall depth $R_{2 h}$; (d) the 3-h maximum rainfall depth $R_{3 h}$; (e) the 4-h maximum rainfall depth $R_{4 h}$; (f) the 5-h maximum rainfall depth $R_{5 h}$; (g) the 6-h maximum rainfall depth $R_{6 h}$; (h) the total rainfall depth $R_{t}$; and (i) the rainfall duration time $D$ in the Oui-mi River basin.

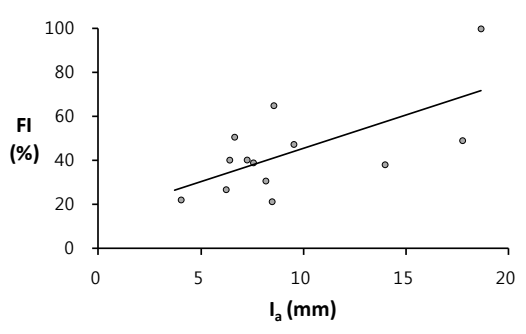

(a)

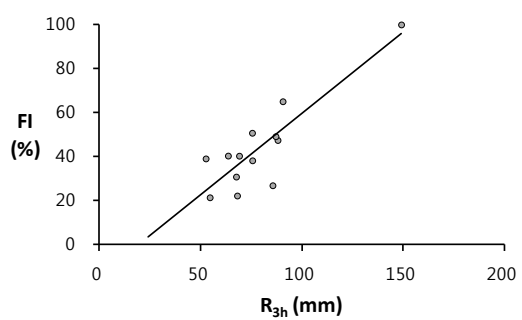

(d)

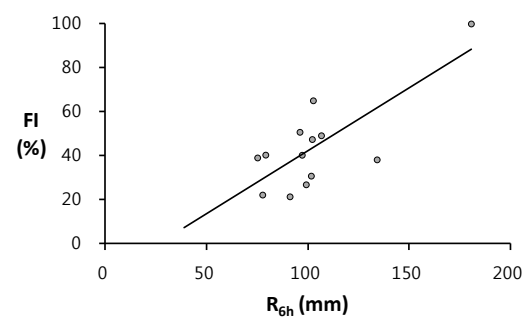

(g)

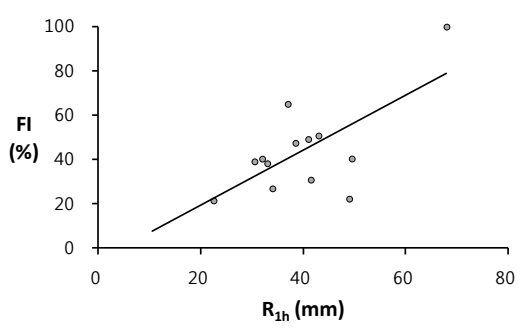

(b)

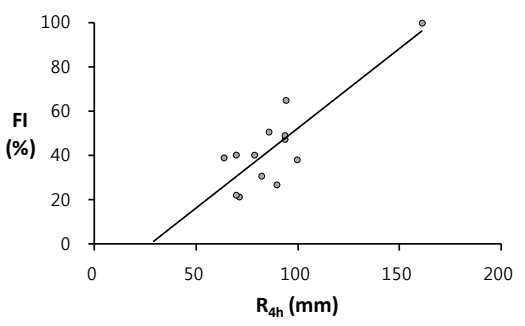

(e)

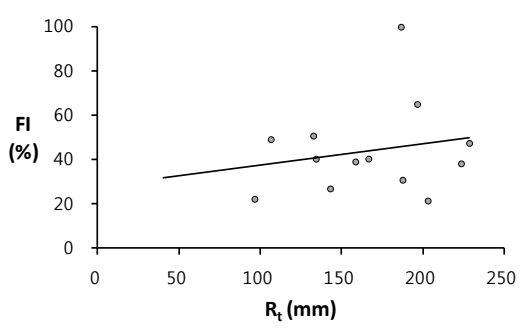

(h)

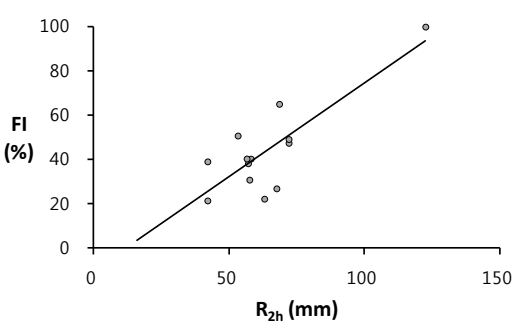

(c)

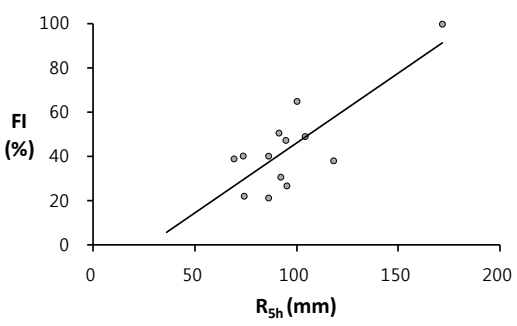

(f)

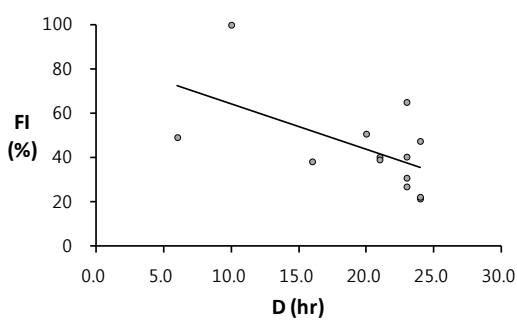

(i) 
Figure 3. The comparison of trends between the flash flood index FI and rainfall characteristics such as; (a) the average rainfall intensity $I_{a}$; (b) the 1-h maximum rainfall depth $R_{1 h}$; (c) the 2-h maximum rainfall depth $R_{2 h}$; (d) the 3-h maximum rainfall depth $R_{3 h}$; (e) the 4-h maximum rainfall depth $R_{4 h}$; (f) the 5-h maximum rainfall depth $R_{5 h}$; (g) the 6-h maximum rainfall depth $R_{6 h}$; (h) the total rainfall depth $R_{t}$; and (i) the rainfall duration time $D$ in the Mae-gok River basin.

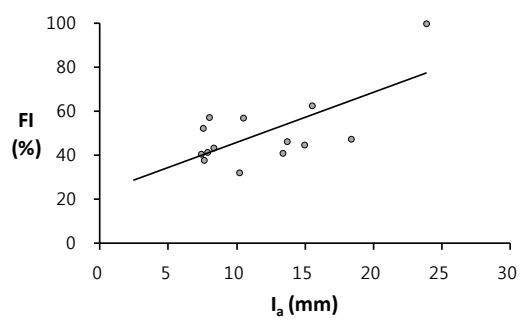

(a)

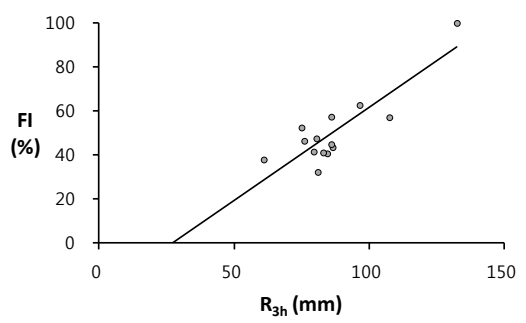

(d)

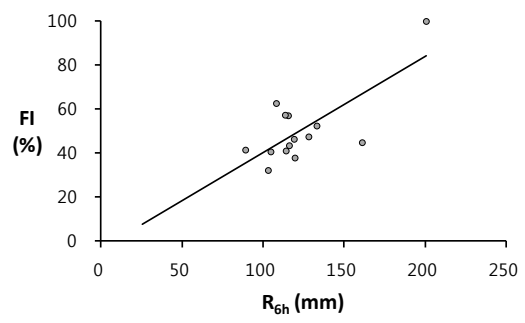

(g)

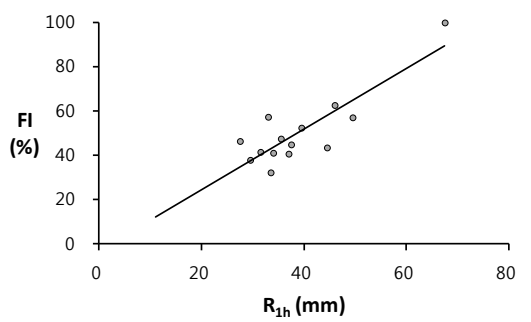

(b)

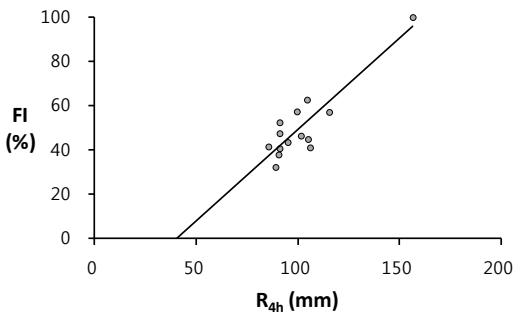

(e)

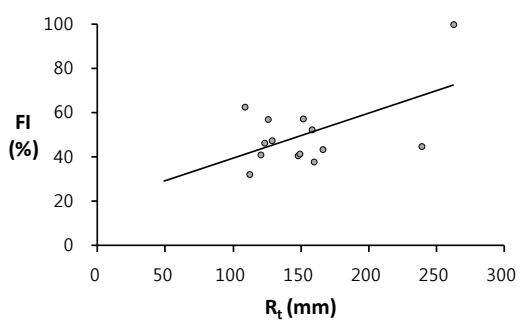

(h)

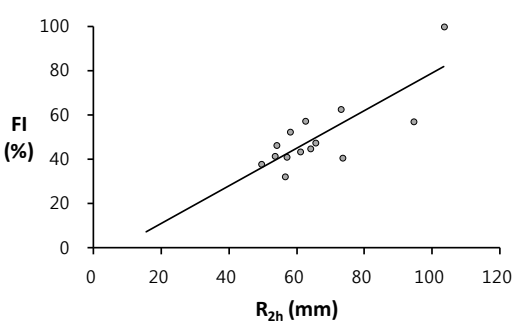

(c)

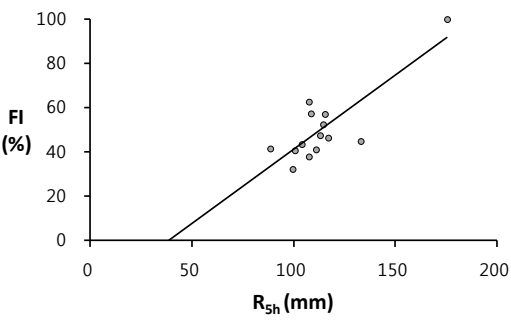

(f)

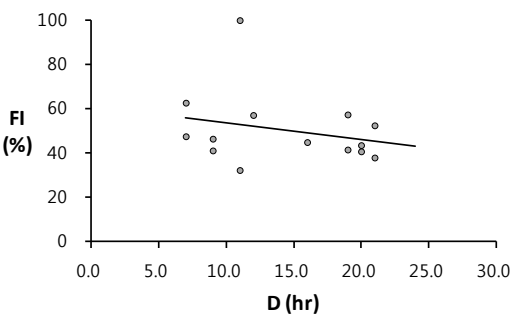

(i)

Table 4. Regression equations for relations between the flash flood index FI and rainfall characteristics.

\begin{tabular}{ccccc}
\hline Rainfall & \multicolumn{2}{c}{ The Oui-mi River } & \multicolumn{2}{c}{ The Mae-gok River } \\
\cline { 2 - 5 } Data & Regression equations & $R^{2}$ & \multicolumn{1}{c}{ Regression equations } & $R^{2}$ \\
\hline$I_{a}$ & $F I=3.023 I_{a}+15.420$ & 0.428 & $F I=2.264 I_{a}+23.435$ & 0.462 \\
$R_{1 h}$ & $F I=1.238 R_{1 h}-5.439$ & 0.450 & $F I=1.370 R_{1 h}-3.003$ & 0.735 \\
$R_{2 h}$ & $F I=0.846 R_{2 h}-10.087$ & 0.669 & $F I=0.848 R_{2 h}-5.644$ & 0.642 \\
$R_{3 h}$ & $F I=0.740 R_{3 h}-14.331$ & 0.753 & $F I=0.845 R_{3 h}-22.946$ & 0.740 \\
$R_{4 h}$ & $F I=0.721 R_{4 h}-19.779$ & 0.728 & $F I=0.826 R_{4 h}-33.379$ & 0.800 \\
$R_{5 h}$ & $F I=0.634 R_{5 h}-17.090$ & 0.636 & $F I=0.669 R_{5 h}-25.770$ & 0.682 \\
$R_{6 h}$ & $F I=0.571 R_{6 h}-14.848$ & 0.580 & $F I=0.437 R_{6 h}-3.401$ & 0.538 \\
$R_{t}$ & $F I=0.097 R_{t}+27.929$ & 0.039 & $F I=0.202 R_{t}+19.435$ & 0.306 \\
$D$ & $F I=-2.060 D+84.932$ & 0.325 & $F I=-0.767 D+61.496$ & 0.065 \\
\hline
\end{tabular}


The flash flood index FI shows the strong relation to some rainfall data with relatively high coefficients of determination $R^{2}$ for each study basin. It demonstrates that the flash flood index FI can be used as a key indicator to estimate the relative flood severity in these study basins. The Oui-mi River basin has the highest relation between the flash flood index FI and the 3-h maximum rainfall depth $R_{3 h}$ with the coefficient of determination $R^{2}$ of 0.753 as shown in Figure $2 \mathrm{~d}$. The trend between the flash flood index FI and the 4-h maximum rainfall depth $R_{4 h}$ shows the best-fit line with the coefficient of determination of 0.800 for the Mae-gok River basin as illustrated in Figure 3e. The flash flood index FI shows the highest linear relation with the rainfall for a shorter duration in the Oui-mi River basin located at the mountainous region with a smaller area size than in a relatively larger flat watershed of the Mae-gok River basin. It is also observed that the flash flood index FI has weak and limited relationship to the average rainfall intensity $I_{a}$ as well as the total rainfall amount $R_{t}$ and duration $D$ in both study basins as shown in Figures 2 and 3(a,h,i). These results support that a local flash flood in small watersheds is mainly caused by heavy or excessive rainfall in a short period of time. Overall, the coefficients of determination $R^{2}$ for regression equations in the Oui-mi River basin are less than those in the Mae-gok River basin as summarized in Table 4.

\section{Discussion and Conclusions}

This study has characterized the severity of flash floods using a dimensionless index describing characteristics of hydrographs generated from a rainfall-runoff model for the long-term observed rainfall data in small ungauged catchments. A new flash flood index FI is determined by the average of relative severity factors $R K$ for the rising curve gradient $K$ and $R M$ for the flood magnitude ratio $M$, which are standardized by the highest recorded maximum value. The developed new flash flood index FI was implemented for the two selected small ungauged basins in Korea, the Oui-mi River basin for the hill slope terrain region and the Mae-gok River basin for the flat region. Since most current flood forecasting and warning systems based on a rainfall-runoff model are not adequate for use in predicting local flooding that occurs in small catchments with the short flood response time, it is necessary to predict the flash flood severity directly by rainfall patterns for the effective emergency preparedness and initial response information to flash flooding. This study has therefore investigated the relationship of rainfall characteristics to the flash flood index FI estimated in the two study basins.A stronger relation of the flash flood index FI to the short term rainfall rather than the total rainfall depth illustrates that heavy or excessive rainfall in a short period of time mainly causes local flash flooding in small watersheds. The proposed flash flood index FI that has a very high relation to linear of a certain rainfall pattern can measure the relative flood severity of a flood event to the highest recorded maximum flood level, which can promptly provide the preliminary information for use in the flash flood preparedness. In comparison of results from the two study basins, it is observed that the flood behavior of the Oui-mi River basin located at the mountainous region with the smaller area size is strongly influenced by the excessive rainfall in a shorter period of time as compared with the result from the Mae-gok River basin, a relatively larger flat watershed. The coefficients of determination $R^{2}$ in the Mae-gok River basin are much higher than those in the Oui-mi River basin for most regression equations. It is partially implicated in the use of point rainfall data measured around the basin, which may not adequately capture high spatial variation of rainfall over the hilly terrain region of the Oui-mi 
River basin, while this effect is less in the flat region of the Mae-gok River basin. It is therefore expected that availability of higher spatial resolution rainfall data may provide a significant improvement to flash flood forecasting in order to cope with the consistent treat of flash flood disasters. Note that this proposed flash flood index does not present any threshold indicators such as the flash flood guidance that should be associated with the current soil moisture condition. For use of the flash flood index FI in a practical flash flood warning or alert system in the future, more tests and implementations need to be conducted with the real severity and damages reported from past floods in a large number of watersheds.

The key to flash flood forecasting is to quickly predict when the flood is above a predetermined threshold level, where a bankfull discharge can occur. The further research needs to investigate the uncertainty in determining of a threshold flooding discharge assumed as the 2-year return period flow in this study. Because the recurrence interval relations for the bankfull discharge are intrinsically different for channels, field verification is recommended to insure that the selected discharge can reflect the bankfull stage on the channel. Alternatively, regionalization analysis of several values from a few gauged catchments can be used to estimate the bankfull discharge for ungauged catchments. The flash flood index FI is based on flood runoff hydrographs simulated from a rainfall-runoff model, HEC-HMS. Since the HEC-HMS model simulated all time series of annual maximum floods systematically for this analysis no matter how much the simulation results depart from the actual runoff, it can be reasonable for the flash flood index FI from the simulated hydrographs to measure the relative severity of a flood event to the highest maximum recorded flood. The uncertainty of the HEC-HMS model itself, albeit it is a generalized modeling system designed to simulate the rainfall-runoff processes of many various watersheds, and calibration parameters used in the rainfall-runoff simulations could be investigated in another research if necessary. Although the current relation results between the flash flood index FI and rainfall characteristics are not conclusive for forecasting local flash floods, it is expected that the proposed flash flood indexing methodology can provide the basic database of preliminary observations for use in an emergency preparedness and response system to flash flood disasters.

\section{Acknowledgments}

This research was supported by the Yeungnam University research grants in 2012 (212A380027).

\section{Conflict of Interest}

The authors declare no conflict of interest.

\section{References}

1. Intergovernmental Panel on Climate Change (IPCC). Fourth Assessment Report, Climate Change 2007-Summary for Policymakers; IPCC: Geneva, Switzerland, 2007.

2. Korea National Emergency Management Agency (KNEMA). The Annual Natural Disaster Bulletin; KNEMA: Seoul, Korea, 2010. 
3. Sweeney, T.L. Modernized Areal Flash Flood Guidance; NOAA Technical Report NWS HYDRO 44; National Weather Service: Springfield, VA, USA, 1992.

4. Shin, H.S.; Kim, H.T.; Park, M.J. The study of the fitness on calculation of the flood warning trigger rainfall using GIS and GCUH. J. Korea Water Resour. Assoc. 2004, 37, 407-424.

5. Kim, B.S.; Kim, H.S. Estimation of the flash flood severity using runoff hydrograph and flash flood index. J. Korea Water Resour. Assoc. 2008, 41, 185-196.

6. Marchi, L.; Borga, M.; Preciso, E.; Gaume, E. Characterisation of selected extreme flash floods in Europe and implications for flood risk management. J. Hydrol. 2010, 394, 118-133.

7. Doswell, C.A., III. Flash Flood-Producing Convective Storms. In Proceedings of the U.S.-Spain Workshop on Natural Hazards, Barcelona, Spain, 8-11 June 1993; pp. 97-107.

8. Lapenta, K.D.; McNaught, B.J.; Capriola, S.J.; Giordano, L.A.; Little, C.D.; Hrebenach, S.D.; Carter, G.M.; Valverde, M.D.; Frey, D.S. The challenge of forecasting heavy rain and flooding throughout the Eastern Region of the National Weather Service. Part I: Characteristics and events. Weather Forecast. 1995, 10, 78-90.

9. Opitz, H.H.; Summer, S.G.; Wert, D.A.; Snyder, W.R.; Kane, R.J.; Brady, R.H.; Stokols, P.M.; Kuhl, S.C.; Carter, G.M. The challenge of forecasting heavy rain and flooding throughout the Eastern Region of the National Weather Service. Part II: Forecast techniques and applications. Weather Forecast. 1995, 10, 91-104.

10. Smith, J.A.; Baeck, M.L.; Zhang, Y.; Doswell, C.A., III. Extreme rainfall and flooding from supercell thunderstorms. J. Hydrometeorol. 2001, 2, 469-489.

11. Rogash, J.A.; Racy, J. Some meteorological characteristics of significant tornado events occurring in proximity to flash flooding. Weather Forecast. 2002, 17, 155-159.

12. Borga, M.; Anagnostou, E.T.; Frank, E. On the use of real-time radar rainfall estimates for flood prediction in mountainous basins. J. Geophys. Res. 2000, 105, 2269-2280.

13. Salek, M.; Brezkova, L.; Novak, P. The use of radar in hydrological modeling in the Czech Republic_-Case studies of flash floods. Nat. Hazards Earth Syst. Sci. 2006, 6, 229-236.

14. Vivoni, E.R.; Entekhabi, D.; Bras, R.L.; Ivanov, V.Y.; van Horne, M.P.; Grassotti, C.; Hoffman, R.N. Extending the predictability of hydrometeorological flood events using radar rainfall nowcasting. J. Hydrometeorol. 2006, 7, 660-677.

15. Smith, J.A.; Baeck, M.L.; Meierdiercks, K.L.; Miller, A.J.; Krajewski, WF. Radar rainfall estimation for flash flood forecasting in small urban watersheds. Adv. Water Resour. 2007, 30, 2087-2097.

16. Villarini, G.; Smith, J.A; Baeck, M.L.; Sturdevant-Rees, P.; Krajewski, W.F. Radar analyses of extreme rainfall and flooding in urban drainage basins. J. Hydrol. 2010, 381, 266-286.

17. Costa, J.E. A comparison of the largest rainfall-runoff floods in the United States with those of the People's Republic of China and the world. J. Hydrol. 1987, 96, 101-115.

18. Perry, C.A. Significant Floods in the United States during the 20th Century: USGS Measures a Century of Floods; USGS Fact Sheet FS-024-00; U.S. Department of the Interior: Washington, DC, USA and U.S. Geological Survey: Reston, VA, USA, 2000.

19. O’Connor, J.E.; Costa, J.E. Large Floods in the United States: Where They Happen and Why; U.S. Geological Survey: Reston, VA, USA, 2003. 
20. Gaume, E. Post Flash-Flood Investigation-Methodological Note; Report D23Đ2; Floodsite European Research Project: Wallingford, UK, 2006.

21. Jarrett, R.D.; Costa, J.E. 1976 Big Thompson Flood, Colorado-Thirty Years Later; U.S. Geological Survey Fact Sheet 2006-3095; U.S. Geological Survey: Reston, VA, USA, 2006.

22. Costa, J.E.; Jarrett, R.D. An Evaluation of Selected Extraordinary Floods in the United States Reported by the U.S. Geological Survey and Implications for Future Advancement of Flood Science; Scientific Investigations Report 2008-5164, U.S. Geological Survey: Reston, VA, USA, 2008.

23. Gaume, E.; Borga, M. Post-flood field investigations in upland catchments after major flash floods: Proposal of a methodology and illustrations. J. Flood Risk Manag. 2008, 1, 175-189.

24. Gaume, E.; Bain, V.; Bernardara, P.; Newinger, O.; Barbuc, M.; Bateman, A.; Blaskovicova, L.; Bloschl, G.; Borga, M.; Dumitrescu, A.; et al. A collation of data on European flash floods. J. Hydrol. 2009, 367, 70-78.

25. Marchi, L.; Borga, M.; Preciso, E.; Sangati, M.; Gaume, E.; Bain, V.; Delrieu, G.; Bonnifait, L.; Pogačnik, N. Comprehensive post-event survey of a flash flood in Western Slovenia: Observation strategy and lessons learned. Hydrol. Process. 2009, 23, 3761-3770.

26. Marchi, L.; Borga, M.; Preciso, E.; Gaume, E. Characterisation of selected extreme flash floods in Europe and implications for flood risk management. J. Hydrol. 2010, 394, 118-133.

27. Borga, M.; Boscolo, P.; Zanon, F.; Sangati, M. Hydrometeorological analysis of the August 29, 2003 flash flood in the Eastern Italian Alps. J. Hydrometeorol. 2007, 8, 1049-1067.

28. Norbiato, D.; Borga, M.; Degli Esposti, S.; Gaume, E.; Anquetin, S. Flash flood warning based on rainfall depth-duration thresholds and soil moisture conditions: An assessment for gauged and ungauged basins. J. Hydrol. 2008, 362, 274-290.

29. Norbiato, D.; Borga, M.; Dinale, R. Flash flood warning in ungauged basins by use of the flash flood guidance and model-based runoff thresholds. Meteorol. Appl. 2009, 16, 65-75.

30. Rossa, A.; Laudanna Del Guerra, F.; Borga, M.; Zanon, F.; Settin, T; Leuenberger, D. Radar-driven high-resolution hydro-meteorological forecasts of the 26 September 2007 Venice flash flood. J. Hydrol. 2010, 394, 230-244.

31. Braud, I.; Roux, H.; Anquetin, S.; Maubourguet, M.M.; Manus, C.; Viallet, P.; Dartus, D. The use of distributed hydrological models for the Gard 2002 flash flood event: Analysis of associated hydrological processes. J. Hydrol. 2010, 394, 162-181.

32. Fread, D.L. National Weather Service River Mechanics: Some Recent Development. In Proceedings of the U.S./PRC Flood Forecasting Symposium/Workshop, Shanghai, China, 14-17 April 1992; pp. 81-111.

33. Carpenter, T.M.; Georgakakos, K.P. GIS-Based Procedures in Support of Flash Flood Guidance; Iowa Institute of Hydraulic Research Report No. 366; Iowa Institute of Hydraulic: Iowa City, IA, USA, 1993.

34. Carpenter T.M.; Sperfslage, J.A.; Georgakakos, K.P.; Sweeney, T.; Fread, D.L. National threshold runoff estimation utilizing GIS in support of operational flash flood warning systems. J. Hydrol. 1999, 224, 21-44.

35. Hall, M.J.; Zaki, A.F.; Shahin, M.A. Regional analysis using the geomorphoclimatic instantaneous unit hydrograph. Hydrol. Earth Syst. Sci. 2001, 5, 93-102. 
36. Kyiamah, G.K. Monitoring and Characterization of Flash Floods. M.S. Thesis, Department of Civil Engineering, University of Louisville, Louisville, KY, USA, 1996.

37. Bhaskar, N.R.; French, B.M.; Kyiamah, G.K. Characterization of flash floods in Eastern Kentucky. J. Hydrol. Eng. ASCE 2000, 5, 327-331.

38. Jung, J.C. The Study on Estimation of the Flash Flood Index for the Bo-Chun River Basin. M.S. Thesis, Department of Civil Engineering, Suwon University, Kyeonggi Province, Korea, 2000.

39. Kim, E.S.; Choi, H.I. Assessment of vulnerability to extreme flash floods in design storms. Int. J. Environ. Res. Public Health 2011, 8, 2907-2922.

40. Wonju City Government. The Basic Plan Report for the Oui-mi River Maintenance Works; Wonju City Government: Gangwon Province, Korea, 2007.

41. Chungcheongnam Province Government. The Basic Plan Report for the Mae-gok River Maintenance Works; Chungcheongnam Province Government: Chungcheongnam, Korea, 2004.

42. U.S. Army Corps of Engineers (USACE). Hydrograph Modeling System; Technical Reference Manual; Hydrologic Engineering Center: Davis, CA, USA, 2000.

43. U.S. Natural Resources Conservation Service (NRCS). Urban Hydrology for Small Watersheds; Technical Release 55 (TR-55); U.S. Department of Agriculture (USDA): Washington, DC, USA, 1986.

44. Clark, C.O. Storage and the unit hydrograph. Trans. ASCE 1945, 110, 1419-1446.

45. Williams, G.P. Bankfull discharge of rivers. Water Resour. Res. 1978, 14, 1141-1154.

46. Wolman, M.G.; Leopold, L.B. River Flood Plains: Some Observations on Their Formation; Professional Paper 282-C; U.S. Geological Survey: Reston, VA, USA, 1957.

(C) 2012 by the authors; licensee MDPI, Basel, Switzerland. This article is an open access article distributed under the terms and conditions of the Creative Commons Attribution license (http://creativecommons.org/licenses/by/3.0/). 